\title{
On the Construction of Mobile Intelligent Terminal-based Business English E-learning Mode
}

\author{
Weilong Huang \\ School of Foreign Languages, Neijiang Normal University, Neijiang 641199, China \\ huberthuang@126.com
}

Keywords: Connectivism, interactive learning, e-learning activities, e-learning assessment.

\begin{abstract}
The rapid development of information technologies greatly facilitates the construction of e-learning mode, and the theory of Connectivism provides a theoretical basis for e-learning mode. This paper analyzes the subjectivity, situationality and openness characteristic of business English e-learning, and proposes to establish a mobile intelligent terminal-based e-learning resource platform and strengthen the implementation of interactive learning. Meanwhile, e-learning activities should be stratified and e-learning assessment should be reorganized to improve the overall effect of business English learning.
\end{abstract}

\section{Introduction}

In business English teaching, the reliance on textbook materials and the neglect of introducing online resources have resulted in the deficiency of limited learning materials and single learning style. Business English learners, for having single and passive learning style, are extremely lacking in their subjective learning and interactive learning. In information age, the output of business information is increasingly massive and the updating of business knowledge is accelerating, thus highlighting the half life of non-linear business English knowledge. Therefore, it is of great necessity to introduce e-learning mode to business English teaching, to keep up with the social development requirement of information quality on business practitioners.

The rapid development of information technologies like mobile intelligent terminal greatly facilitates the construction of e-learning mode. The learning theory of Connectivism is a forward-looking theory for an in-depth understanding of the law of online learning in the open age of network", which provides a theoretical basis for building e-learning mode. It views learning as the formation of knowledge networks, in which learners can achieve the connection of knowledge nodes in library, website, books, cafes, etc., realize certain form of knowledge processing, and achieve "resource-based autonomous learning and interactive learning-based autonomous learning." [1] With the guidance of the theory of Connectivism, the network technology can be fully utilized to achieve the connection of knowledge nodes, achieve the cycle of knowledge growth, and cultivate learners' "access to information, analysis of information, and ability to solve practical problems."[2] E-learning is defined as "the use of new multimedia technologies and the Internet to improve the quality of learning by facilitating access to resources and services as well as remote exchanges and collaboration." [3] Connectivism can not be strictly taken as a "learning theory"; instead, it should be seen as a "learning view", that is, "learning is the formation of connections in network". [4] The formation of connections is indispensable from the subjective learning, situated learning and open learning. In Business English e-learning, the characteristics of subjectivity, situationality and openness cannot be neglected since it lays the foundation for efficient use of e-learning resources and the formation of interactive learning. 


\section{Characteristics of Business English E-learning}

\subsection{Subjectivity}

The knowledge of business English is fragmented, interdisciplinary and practical, so students need to actively participate in subjective learning, either for the construction of non-linear business English knowledge system, or for the cultivation of business communication skills. Business English learners are likely to acquire subjective learning in the environment of e-learning mode. Subjective learning mobilizes their initiative of business English learning, enables them to speed up the construction of business English knowledge system, enhances their business practice ability, and develops their cross-cultural communication.

\subsection{Situationality}

The development of business English learners' business communication and practical skills can not be separated from the support of situated teaching resources. With the maturing of Internet technologies, business English e-learning platform can provide a variety of resources, including text, pictures, audio clips and video clips. Meanwhile, the availability of simulative business scenes and other contextualized resources make learners incorporate into corporate projects and company cases more easily, and facilitate the realization of the connection of knowledge nodes and the "creation, sustainable development and optimization of networks." [5] It will not only enrich the student's learning experience, but also "enable learners to use the relevant knowledge and experience of their own cognitive structure, to assimilate what is learned, and to give a certain meaning to new knowledge." [6]

\subsection{Openness}

E-learning mode only exists in an open learning environment, where business English learners can get access to the online resources of different courses anytime and anywhere. This allows them to spend their spare time on the distribution and connection of fragmented knowledge, and thus greatly expands their horizon of business knowledge. In business English courses, students need to acquire certain knowledge reserve while it is impossible to systematically introduce fragmented knowledge in class. In this sense, the openness of business English e-learning makes up for this constraint.

\section{Proposals of Constructing E-learning Mode}

\subsection{Establish a Mobile Intelligent Terminal-based E-learning Resource Platform}

The construction of business English e-learning is inseparable from the support of network technology, and relying on network technology to establish a large platform of e-learning resources is the premise for students to complete the e-learning activities. Accordingly, proper e-learning platform needs to be constructed to provide e-learning resources. Here, the author proposes to establish a mobile intelligent terminal-based e-learning platform. Among many mobile intelligent terminals, WeChat seems to be the ideal mobile application software since it integrates entertainment, communication and social intercourse with many integrated platform functions. With the availability of information distribution through text, pictures, video clip and audio clip, and the support for group chat and video communication, it provides an ideal way to create three-dimensional network resources and achieve interactive learning. WeChat provides the function of Circle of Friends, supports mail service, microblogging and other services, and enriches social network scene. Besides, the Official Account of WeChat has simple interface and can be easily opened for free to push business English e-learning resources to subscribers, thus providing an ideal technical framework support for common resource developers like business English teachers. In addition, the great popularity of WeChat among college students is the guarantee for the promotion of e-learning resource platform.

\subsection{Strengthen the Implementation of Interactive Learning}

The view of learning advocated by Connectivism puts interactive learning at the core. "In Connectivism, interaction is typically crucial." [4] Media-centered interaction realizes the key to the reintegration of teaching and learning. Different from the concept of interaction in constructivism, interaction not only refers to the interactive and cooperative learning between teachers and students, 
and among students, but also includes interaction between learners and network nodes. The nature of interaction is the process of "helping learners achieve learning goals, and making the subject achieve mutual exchange and interaction in the learning environment."[5] In Connectivism learning, learners' learning objectives are the establishment of node connections, and the creation, sustainable development and optimization of (cognitive, social, conceptual) network creation. The subjects of teaching interaction has reached unprecedented diversification, including promoters, learners, groups, interpersonal networks and other subjects, including learning content, learning resources, and a variety of technical media. The relations of interaction between these subjects constitute an open and diverse educational interaction environment.

In business English e-learning, interactive learning includes the interaction between business English learners and teachers, the interaction among business English learners, and the interaction between business English learners and el-learning platform. For example, teachers can push business news, fragmented business theory and business English terms to students through the Official Account opened on WeChat, where students can get access to these learning materials easily and make their own comment on the online materials, which will help teachers update, revise and supplement learning resources. In this way, both teachers and students achieve the interaction with learning materials and it promotes the construction of e-learning resource platform. With the function of group chat and private chat on WeChat platform, students can interact with each other or communicate with teachers easily.

\section{Stratification of Business English E-learning Activities}

Based on Bloom's classification of cognitive objectives, cognitive objectives can be stratified into six levels from low to high: knowledge, comprehension, application, synthesis, evaluation. [7] Since business English learners differ in their cognitive levels, e-learning activities can be stratified so that they can prefer what activities fit into their cognitive level and give full play to their interactive learning in business English e-learning. Based on the six levels of cognitive objectives, this paper proposes to stratify business English e-learning activities into three levels.

The first level is based on the objectives of knowledge and comprehension, which requires student to identify, memorize and comprehend business English-related knowledge and theory, like business English vocabulary, terminology, and business English writing templates, so as to facilitate the accumulation of their business English knowledge reserve. The second level of activities is based on the cognitive objectives of application and analysis. Business courses not only cover basic business knowledge and theory, but also include many scenarios that engage learners' analysis and application. Be it business case analysis, business English writing practice or business English translation, they need to reflect on what has been learned and apply what they learn to reality. The third level of activities is based on the cognitive objectives of synthesis and evaluation, which require them to build a new structure or make judgment about the value of ideas or materials. Teachers can assign group project as group work so that students themselves will divide the work, collaborate with each other and finally complete the project. Meanwhile, teachers can encourage other students to make comment or assessment on individual performance, group work and e-learning materials, which is beneficial to the development of their critical thinking. When designing the three levels of e-learning activities for Business English e-learning, teachers should take into account the needs of students and the characteristics and requirements of courses.

\section{Reorganization of Business English E-learning Assessment}

Priority should be given to formative assessment in e-learning assessment to encourage students' subjective learning. Through e-learning platform background, it is easy to collect students' personal learning data, like the number of logging, and evaluate the performance of group work or individual work.

The object of e-learning assessment should be extended to business English e-learning resources constructed by teachers and learners. Teachers should play the leading role in resource construction, 
examining whether the business English resources are consistent with the teaching objectives, whether the business English resources can adapt to business practice and curriculum setting. On the other hand, teachers should strengthen the guidance, review and incentives on the construction of resources by students, in order to achieve a benign ecological cycle of building business English e-learning resources by teachers and students.

The subject of business English e-learning assessment should be diversified. For individual work, self-assessment, peer assessment, and teacher assessment can be integrated, which will greatly release students' engagement in business English e-learning.

What's more, the overall assessment on the integration effectiveness of e-learning and classroom learning should be strengthened. E-learning is the extension and development of classroom learning, while classroom learning is the basis and guarantee of online learning. Whether e-learning and classroom learning can achieve deep integration is the key to the improvement of overall effect of business English learning. Therefore, the preview of online business English content will lay foundation for classroom learning and further mobilize the enthusiasm of business English e-learning, thus achieving the connection of students, network resources, classroom in the words of Connectivism. In addition, limited to time and space, project cooperation often begins in the classroom, and most of the project work has to be completed outside classroom. Therefore, it is necessary to assess whether e-learning gets fully integrated into classroom teaching.

\section{Conclusion}

Business English e-learning is characterized by subjectivity, situationality and openness. In the construction of business English e-learning mode, great efforts should be made to construct mobile intelligent terminal-based business English e-learning resource platform, and strengthen the implementation of interactive learning. E-learning activities should be stratified to meet the cognitive levels of students and the characteristics of business courses, and e-learning assessment should give priority to formative assessment, resource construction and assessment subjects should be extended to students. Meanwhile, whether e-learning and classroom learning can achieve deep integration should be assessed, so as to improve the overall effect of business English learning.

\section{Acknowledgements}

This work was financially supported by "The Project for the Reform of Teaching and Education in Neijiang Normal University (JG201515-293)”.

\section{References}

[1] J. Qiao, R.H. Wu, C.P. Xiong, Analysis on Application and Prospect of Mobile Intelligent Terminal in Teaching, A Journal of Modern Special Education, 2(2013) 81.

[2] Z.Y. Zhou, The Nature of E-learning, Distance Education in China, 9(2005)34.

[3] Information on https://www.researchgate.net/publication/30868993_The_eLearning_Action_Plan_-_Designing_ Tomorrow.

[4] Z.J. Wang, L. Chen, Learning Theory of Connectivism and Its Latest Developments. Open Education Research, 5(2014) 17-21.

[5] Z.J. Wang, L. Chen, A Study on the Construction of Teaching Interaction Theory Model Based on Connectivism Learning, Open Education Research, 5(2015) 27.

[6] J. Tang, On Situational Learning Strategies Based on the Network Environment, Shanghai Research on Education, 11(2004)35.

[7] L. W. Anderson, et al, A Taxonomy for Learning, Teaching and Assessing, Shanghai, East China Normal University Press, 2007, pp58-76. 